\title{
PENINGKATAN DAN PENGEMBANGAN DAYA SAING BAGI UMKM KRIPIK SALAK DI KABUPATEN SLEMAN
}

\author{
Dian Retnaningdiah ${ }^{1)}$ \\ Retno Ika Sundari ${ }^{2)}$ \\ Eko Riswanto $^{3)}$ \\ Paryanto ${ }^{4)}$ \\ ${ }^{1)}$ Fakultas Ekonomi, Universitas Widya Mataram Yogyakarta \\ e-mail: dian_rdh@yahoo.co.id \\ ${ }^{2)}$ Fakultas Ekonomi, Universitas Widya Mataram Yogyakarta \\ e-mail: retno.ika79@gmail.com \\ ${ }^{3}$ STIMIK El-Rahma Yogyakarta \\ e-mail: riswantoeko@yahoo.com \\ ${ }^{4)}$ Universitas Negeri Yogyakarta \\ e-mail: parymsn@yahoo.co.id
}

\begin{abstract}
Today improving and developing competitiveness for Micro, Small and Medium Enterprises (SMEs) become very important for the development of Indonesian economy. SMEs play an important role in supporting the development of regional economy, which will ultimately have an impact on the national economy. SMEs in Sleman district engaged in the processing zalacca chips, its existence gives a positive value in the economy. Support and attention from stakeholders are very necessary for the sustainability of its business. This programs try to provide an explanation of the importance of the role of human resource innovation capability and technological strategies such as information technology and appropriate technology to support the development and improvement of the competitiveness of SMEs, especially for businessmen of zalacca chips in order to be able to play in the global markets.
\end{abstract}

Keywords: human resource, innovation, technology strategy, SMEs competitiveness, zalacca chips

\section{PENDAHULUAN}

Peranan usaha mikro, kecil, dan menengah (UMKM) dalam perekonomian Indonesia adalah sentral. Jumlah industrinya yang besar dan terdapat dalam setiap sektor ekonomi, potensinya dalam penyerapan tenaga kerja, bila dibandingkan dengan perusahaan besar serta sumbangannya terhadap pembentukan PDB dan devisa Negara melalui nilai ekspor membuat UMKM menjadi suatu bentuk badan usaha yang sangat diperhitungkan. Keberhasilan UMKM bertahan dalam krisis tidak serta merta menjadikan UMKM mampu berkembang dengan baik. UMKM masih sering mengalami masalah dalam mengembangkan usahanya diantaranya pemasaran produk, teknologi, kualitas sumber daya manusia (SDM) hingga pengelolaan keuangan. Pengelolaan keuangan melalui penerapan kaidah akuntansi yang baik dan benar terkadang diabaikan para pelaku UMKM.

Keunggulan UMKM mampu menyerap tenaga kerja hingga lebih kurang 87\%90\% sedangkan sumbangan terhadap PDB 54\% (Rahab dan Sudjono 2012). Hal ini mengindikasikan bahwa pada dasarnya UMKM merupakan kelompok usaha yang 
memiliki potensi besar untuk mengatasi pengangguran dan kemiskinan. Daya saing UMKM merupakan hal penting dalam mengembangkan sektor riil yang memiliki potensi penyerapan tenaga kerja. Penyerapan tenaga kerja juga perlu diukur untuk menilai sejauh mana kinerja UMKM tersebut. Kinerja yang baik akan suatu usaha dapat dilihat sejauhmana usaha tersebut mengembangkan inovasi dalam rangka mempertahankan keberlangsungan hidupnya. Proses pengembangan kapabilitas inovasi aspek pasar, kewirausahaan, dan pembelajaran organisasi memainkan peran penting bagi organisasi (Suliyanto dan Rahab 2010).

Masalah yang masih dihadapi UMKM adalah rendahnya produktivitas (Sri Susilo, 2005). Hal tersebut berkaitan dengan rendahnya kualitas SDM dan rendahnya kompetensi kewirausahaan. Di samping itu, UMKM menghadapi faktor-faktor yang masih menjadi kendala dalam peningkatan daya saing dan kinerja UMKM. Faktor-faktor tersebut diantaranya adalah: (1) terbatasnya akses permodalan, (2) terbatasnya akses pasar, dan (3) terbatasnya akses informasi mengenai sumber daya dan teknologi.

Berkaitan dengan perdagangan bebas, sejak Januari 2010, Indonesia telah mulai mengimplementasikan kesepakatan China Free Trade Area (CAFTA). Salah satu dampak diberlakukannya CAFTA adalah membanjirnya produk-produk China di pasar Indonesia. Produk-produk tersebut termasuk pesaing dari produk-produk yang dihasilkan oleh UMKM Indonesia, seperti misalnya produk keramik, pakaian jadi, produk alas kaki, mebel, dan produk kerajinan. Hal tersebut merupakan tantangan bagi produk UMKM Indonesia. Di sisi lain CAFTA merupakan peluang bagi produk UMKM Indonesia untuk memasuki pasar China. China dengan jumlah penduduk yang banyak dan pertumbuhan ekonomi yang relatif tinggi merupakan pasar yang sangat potensial bagi produk-produk yang dihasilkan UMKM Indonesia. Diberlakukannya MEA (Masyarakat Ekonomi ASEAN) atau AEC (ASEAN Economic Community) pada tahun 2015, menjadi peluang sekaligus tantangan bagi produk-produk yang dihasilkan UMKM Indonesia. Peningkatan daya saing menjadi faktor penentu utama agar mampu menghadapi tantangan dan memanfaatkan peluang atas diberlakukannya CAFTA tahun 2010 dan MEA tahun 2015 (Sri Susilo, 2010).

Diungkapkan oleh Kuncoro (2010) bahwa di tengah perekonomian Indonesia yang kurang stabil, UMKM dihadapkan pada sejumlah permasalahan: (1) kelemahan dalam memperoleh peluang pasar dan memperbesar pangsa pasar, (2) kelemahan di bidang organisasi dan keterbatasan memperoleh jalur terhadap sumber permodalan, (3) kelemahan di bidang organisasi dan manajemen sumber daya manusia, (4) keterbatasan jaringan usaha kerja sama antar pengusaha kecil (sistem informasi pemasaran), (5) iklim usaha yang kurang kondusif karena persaingan saling mematikan, (6) pembinaan yang telah dilakukan kurang terpadu dan kurangnya kepercayaan serta kepedulian masyarakat terhadap usaha kecil.

Artikel ini mengkaji berbagai permasalahan yang terjadi pada pelaku usaha kripik salak di Kabupaten Sleman dan mencoba memberikan solusi pemecahan. Dua kelompok usaha kripik salak yang akan dikaji adalah Gabungan Kelompok Tani (Gapoktan) "Wono Mulyo" dan Kelompok Wanita Tani (KWT) "Srikandi". Kedua kelompok ini memiliki sejumlah kesamaan permasalahan utama dalam menjalankan usahanya. Permasalahan tersebut berupa kapabilitas inovasi SDM dan strategi teknologi yang merupakan faktor sangat penting dalam menentukan peningkatan kinerja UMKM. Artikel ini merupakan hasil program pengabdian kepada masyarakat. 


\section{METODE PELAKSANAAN}

Kegiatan pengabdian ini dilakukan melalui program pelatihan dan pendampingan usaha dengan permasalahan utama yang dihadapi mitra kapabilitas inovasi SDM dan strategi teknologi diatasi dengan menggunakan rancangan kegiatan dengan berbagai penerapan:

\section{Pelatihan Manajemen Usaha}

Pelatihan manajemen usaha bertujuan untuk mengatasi permasalahan kapabilitas inovasi Sumber Daya Manusia melalui peningkatan skill SDM, khususnya bagi kedua kelompok mitra. Pelatihan ini bertujuan untuk:

1. Meningkatkan pengetahuan dan jiwa wirausaha para pengusaha keripik salak.

2. Meningkatkan kemampuan pembukuan usaha.

3. Meningkatkan pengetahuan dan kemampuan dalam bidang manajemen pemasaran dalam rangka meningkatkan pendapatan usaha.

Secara rinci tahapan-tahapan pelatihan manajemen usaha sebagai berikut:

a. Pelatihan kewirausahaan meliputi materi:

1) Pemahaman pengertian wirausaha, pengenalan ciri-ciri dan watak wirausaha;

2) Strategi mencari celah pasar/menangkap peluang besar;

3) Penyusunan rencana bisnis.

b. Pelatihan pembukuan dan pembuatan laporan keuangan usaha mikro kecil dan menengah.

c. Pelatihan manajemen pemasaran:

1) Strategi penentuan harga;

2) Promosi penjualan;

3) Strategi menghadapi persaingan.

Pelatihan yang akan diberikan kepada mitra bertujuan untuk memberikan tambahan pengetahuan. Adapun langkah-langkah yang akan dilakukan dalam pelaksanaan pelatihan adalah:

a. Merumuskan materi pelatihan yang relevan;

b. Membuat jadwal pelatihan;

c. Menyiapkan bahan dan alat pelatihan;

d. Pembagian tugas instruktur;

e. Pelaksanaan pelatihan;

f. Melaksanakan evaluasi.

\section{Pelatihan Pemanfaatan Teknologi}

Peran teknologi sangat penting dalam suatu perusahaan dan berimplikasi pada kebutuhan untuk mengembangkan strategi teknologi dalam perusahaan. Teknologi akan dapat membantu perusahaan untuk mendapatkan kompetensi pembeda (distinctive competence) yang memungkinkan perusahaan untuk menghasilkan produk yang lebih baik dari pesaingnya (Tidd et.al 1997), sedangkan teknologi yang modern akan membawa peningkatan kualitas produk, pengembangan produk baru, produktivitas, dan efisiensi (Chowdhury, 1990).

Strategi teknologi yang digunakan dalam program pelatihan dan pendampingan ini adalah melalui pemanfaatan Teknologi Tepat Guna dan Teknologi Informasi. 


\section{Teknologi Tepat Guna}

Teknologi Tepat Guna (TTG) dalam rangka untuk meningkatkan kualitas kerja usaha yang telah ada, berdampak pada peningkatan produktivitas, dan pada akhirnya mencapai pada tujuan peningkatan kesejahteraan masyarakat. Adapun TTG yang dipilih adalah:

1. Aluminium Foil Continuous Sealer (AFCS). AFCS yaitu mesin untuk membuat kantung kemasan kripik salak yang terbuat dari aluminium foil.

2. Mesin Generator. Mesin ini digunakan untuk membantu kelancaran proses produksi.

\section{Teknologi Informasi}

Sistem Informasi adalah aplikasi komputer untuk mendukung operasi dari suatu organisasi. Teknologi Informasi yang akan diterapkan bagi kedua kelompok ini adalah teknologi informasi pendukung sistem pemasaran produk melalui pembuatan website. Pemasaran elektronik ini diharapkan membantu UMKM melalui pemanfaatan e-commerce, yaitu kegiatan perdagangan dengan menggunakan media elektronika atau internet. E-commerce ini akan mendukung program perluasan daerah pemasaran yang selama ini dilakukan secara konvensional, dengan daerah pemasaran yang sangat terbatas. berikut:

Pelatihan dan pendampingan pemanfaatan teknologi akan dilaksanakan sebagai

a. Pelatihan dan pendampingan penggunaan mesin AFCS

b. Pelatihan dan pendampingan penggunaan mesin generator

c. Pelatihan dan pendampingan penggunaan disain web

Ruang Lingkup atau objek dalam pengabdian ini adalah kelompok usaha kripik salak Gabungan Kelompok Tani (Gapoktan) "Wono Mulyo" di Turi dan Kelompok Wanita Tani (KWT) "Srikandi” di Pakem, Sleman, DIY. Adapun gambaran kedua objek tersebut adalah:

Kedua kelompok ini mempunyai 5-7 orang dan sebagian besar merupakan warga desa Wonokerto. Tujuan didirikannya Gapoktan Wono Mulyo maupun KWT Srikandi adalah mengembangkan pengetahuan, kemampuan, dan keterampilan usaha tani dan pengolahan hasil pertanian, mengembangkan jiwa kepemimpinan, dan mengembangkan kerja sama jiwa wiraswasta dan kemandirian serta manfaat yang lebih besar bagi para anggotanya secara berkesinambungan. Tujuan ini belum berjalan sebagaimana yang diharapkan.

Kedua kelompok ini, dalam hal proses produksi memiliki kendala terutama pada saat proses penggorengan. Produk yang diolah dengan menggunakan mesin vacuum fryer tersebut, bila terjadi pemadaman listrik berakibat pada buah salak yang sedang digoreng menjadi sia-sia dan tidak bisa diolah lagi. Hal ini jelas sangat merugikan.

Keterbatasan dimiliki juga dalam pemasaran produk. Informasi pemasaran masih sangat terbatas. Program pemberdayaan dari pemerintah masih sebatas pada pelaksanaan program pelatihan pengolahan yang baik (CPBB) dan alat vacuum frier untuk pembuatan keripik salak, serta cara melakukan packaging dan keikutsertaan dalam pameran-pameran secara gratis. Saat mengikuti pameran, hanya pesanan-pesanan kecil dari daerah lokal-lah yang langsung ke pengusaha kripik salak dan bila ada pesanan dari luar daerah atau luar negeri melewati pedagang besar dari pihak pemilik toko yang menjadi tempat di mana keripik salak dititipkan, sehingga omset yang diterima oleh pengusaha kurang maksimal. 


\section{HASIL DAN PEMBAHASAN}

\section{Kapabilitas Inovasi SDM}

Inovasi mungkin merupakan kunci kesuksesan organisasi, akan tetapi tenaga kerja yang mempunyai skill yang tinggi merupakan faktor yang penting untuk inovasi.

Kegiatan pelatihan bagi Gapoktan "Wono Mulyo" dan KWT "Srikandi" dilakukan dalam rangka untuk meningkatkan kapabilitas skillmereka berupa pelatihan kewirausahaan dan manajemen usaha yang diikuti dengan pendampingan, berupa:

a. Pelatihan kewirausahaan. Pelatihan diberikan dalam rangka untuk meningkatkan kualitas jiwa kewirausahaan.

1) Kreativitas merupakan suatu tolak ukur jiwa kewirausahaan. Sebelum dilakukan program pengabdian ini pelaku UMKM kurang memiliki kreativitas, hal ini dibuktikan dengan kemauan berproduksi keripik salak hanya bertujuan mengolah salak segar yang berlimpah saat panen raya agar buah salak segar tidak dibuang percuma. Setelah diadakan pelatihan kewirausahaan ini memberikan suatu pemikiran/ide perlunya kesinambungan usaha, dalam hal ini keberlanjutan siklus produksi yang berkelanjutan baik saat panen raya ataupun tidak proses produksi keripik salak perlu dilakukan secara terus menerus. Salah satu cara yang dilakukan oleh pelaku UMKM adalah dengan memaksimalkan fungsi organisasi Gapoktan dan KWT dengan membuat kesepakatan tertulis mengenai harga, kualitas dan jumlah salak segar.

2) Sikap inovasi pelaku UMKM terlihat dengan adanya sinergi. Hal ini diwujudkan munculnya kesepakatan antara KWT dan Gapoktan dalam melayani permintaan konsumen.

3) Kemampuan melakukan manajemen resiko terlihat dengan adanya penggunaan kemasan alumunium foil yang lebih tepat untuk produk makanan.

Pelatihan kewirausahaan ini bisa dikatakan berhasil, karena hasil pelatihan kewirausahaan ini mencerminkan peran kewirausahaan dalam mengatasi tantangan UMKM (Afiah, 2009).

b. Pelatihan pembukuan usaha. Pelaku usaha pada dasarnya belum memahami pembukuan usaha. Hal ini disebabkan oleh keterbatasan pengetahuan dan kemampuan dalam pembuatan pembukuan usaha. Kebanyakan UMKM hanya mencatat jumlah uang yang diterima dan dikeluarkan, jumlah barang yang dibeli dan dijual, dan jumlah utang/piutang. Namun, pencatatan ini hanya sebatas pengingat saja dan tidak dengan format yang diinginkan oleh pihak perbankan. Meskipun tidak dapat dipungkiri mereka dapat mengetahui jumlah modal akhir mereka setiap tahun yang hampir sama jumlahnya jika kita mencatat dengan sistem akuntansi (Jati, 2004).

Pelaku UMKM kripik salak di Kabupaten Sleman melakukan pembukuan usaha secara tidak rutin, bahkan cenderung terhenti. Hal ini menunjukkan kesadaran dan semangat untuk memahami pentingnya pembukuan usaha belum tertanam dengan baik. Pemberian motivasi melalui pelatihan dan pendampingan rutin sangat diperlukan bagi kelompok usaha ini. Praktik akuntansi, khususnya akuntansi keuangan pada UMKM di Indonesia masih rendah dan memiliki banyak kelemahan (Wahdini dan Suhairi, 2006). Oleh karena itu penting dilakukan pengelolaan pembukuan yang diberikan melalui pelatihan pembukuan berupa pemahaman Laporan Keuangan, melalui: (1) pencatatan transaksi secara tertib, (2) pencatatan pembukuan sederhana, (3) pencatatan pembukuan komputerisasi. 
Program pendampingan sebagai kelanjutan kegiatan pelatihan dilakukan pencatatan dengan penggunaan komputer dalam pembukuan usaha. Pekerjaan ini dilakukan oleh anggota yang sudah memiliki kemampuan menggunakan komputer dengan program MYOB \& Microsoft Office. Adapun metode yang diajarkan adalah aplikasi Microsoft Excell untuk penentuan harga jual dan ongkos produksi, serta pembuatan kartu sediaan dengan menggunakan metode FIFO, sedangkan program MYOB digunakan dalam pembuatan laporan keuangan.

Pemanfaatan MYOB dalam pembukuan usaha sangat diperlukan. MYOB adalah sebuah software akuntansi yang biasa digunakan oleh UKM yang dibuat secara terpadu (integrated software). Pemilihan program MYOB membuat sistem pembukuan pelaku UMKM keripik salak menjadi lebih efektif.

\section{Strategi Teknologi}

Peran teknologi yang sedemikian penting dalam suatu perusahaan berimplikasi pada kebutuhan untuk mengembangkan strategi teknologi dalam perusahaan. Burgelman et al (2001) mengemukakan bahwa teknologi adalah sumberdaya yang penting dalam organisasi yang perlu dikelola dengan baik, karena teknologi merupakan fungsi bisnis yang mendasar. Teknologi akan dapat membantu perusahaan untuk mendapatkan kompetensi pembeda (distinctive competence) yang memungkinkan perusahaan untuk menghasilkan produk yang lebih baik dari pesaingnya (Tidd et.al 1997). Teknologi modern akan membawa peningkatan kualitas produk, pengembangan produk baru, produktivitas dan efisiensi (Chowdhury, 1990).

Teknologi Tepat Guna. Teknologi tepat guna (TTG) adalah teknologi yang sesuai dengan kebutuhan masyarakat dan bisa dimanfaatkan pada saat rentang waktu tertentu, biasanya dipakai sebagai istilah untuk teknologi yang terkait dengan budaya lokal dan digunakan sebagai salah satu jalur penting untuk mencapai tujuan yang mendasar, yakni meningkatkan kesejahteraan masyarakat (Situmorang dan Safri, 2011). Pendayagunaan teknologi tepat guna secara optimal akan dapat terwujud apabila ada alih teknologi dari pencipta atau pemilik teknologi tepat guna kepada masyarakat pengguna teknologi tepat guna. Terdapat beberapa prinsip yang perlu dijadikan acuan yaitu:

1. Pemanfaatan TTG dilakukan dalam rangka meningkatkan kualitas kerja usahausaha yang telah ada, sehingga produktivitas meningkat yang pada tujuan akhirnya meningkatkan kesejahteraan masyarakat.

2. TTG dimanfaatkan untuk menumbuhkan lapangan kerja baru di masyarakat.

3. Walaupun TTG umumnya bukanlah berteknologi tinggi, namun diharapkan adanya proses pendampingan sehingga pemanfaatan TTG tersebut dapat optimal.

Aplikasi penerapan TTG yang berdayaguna dilakukan dengan:

1. Memberikan satu unit mesin continuous sealer. Mesin ini merupakan salah satu jenis mesin sealer yang dapat digunakan untuk perekat plastik maupun aluminium foil. Mesin yang dihibahkan ini mempunyai beberapa kelebihan, yaitu dapat diposisikan baik vertikal maupun horizontal, sehingga sangat fleksibel dapat dimanfaatkan sesuai kebutuhan pelaku usaha, pengaturan temperatur dapat dilakukan dengan mudah sehingga operator dapat menentukan temperatur yang pas/tepat sesuai dengan bahan yang akan dipakai. Kapasitas mesin ini tidak terbatas (artinya panjang berapapun mampu direkatkan dengan mesin ini). Daya listrik yang diperlukan untuk 
pengoperasian mesin ini sebesar 450 watt. Manfaat lain yang diperoleh pelaku UMKM dengan adanya mesin ini adalah terciptanya diversifikasi usaha, berupa pembuatan kantong kemasan dan dijual sehingga dapat menambah pendapatan pelaku UMKM.

2. Memberikan satu unit genset. Genset yang dihibahkan ini memiliki kapasitas output 3.000 watt, hal ini disesuaikan dengan kebutuhan pelaku usaha yaitu untuk menopang kebutuhan listrik untuk mesin vacuum frying yang dimiliki oleh pelaku usaha. Dengan keberadaan genset ini sangat dirasakan manfaatnya oleh pelaku usaha, terutama pada saat terjadi pemadaman listrik, maka pelaku usaha dapat tetap berproduksi, sehingga tetap mampu memenuhi order yang telah disepakati dengan konsumen. Sebelum memiliki genset, proses produksi harus terhenti bilamana terjadi pemadaman listrik, sehingga seringkali mitra mengalami kerugian kegagalan mengolah produk salak segar yang berakibat tidak dapat memenuhi pesanan tepat waktu.

Teknologi Informasi. Sistem informasi adalah aplikasi komputer untuk mendukung operasi suatu organisasi: operasi, instalasi dan perawatan komputer, perangkat lunak, dan data. Sistem Informasi Manajemen adalah kunci pada bidang yang menekankan finansial dan personal manajemen. Sistem Informasi dapat berupa gabungan beberapa elemen teknologi berbasis komputer yang saling berinteraksi dan bekerjasama berdasarkan suatu prosedur kerja (aturan kerja) yang telah ditetapkan, yang memroses dan mengolah data menjadi suatu bentuk informasi yang dapat digunakan dan mendukung keputusan (Mukhyi dan Mujiyana, 2008).

Barang atau produk yang dihasilkan akan bermakna apabila dapat mencapai kesuksesan secara komersial (Byrd, 2000). Pelaku usaha harus mengembangkan kemampuannya untuk memasarkan produk atau pelayanan yang baru tersebut. Baldwin dan Johnson (1995) dalam penelitiannya di Kanada menemukan bahwa perusahaan skala kecil dan menengah akan menjadi lebih inovatif apabila memberikan penekanan yang lebih besar pada pengembangan kapabilitas pemasaran, finansial, produksi dan SDM. Kapabilitas pemasaran dalam kegiatan ini mengacu pada kemampuan perusahaan untuk mengembangkan berbagai aspek yang terkait dengan pemasaran produk meliputi distribusi dan promosi.

Salah satu bentuk penerapan teknologi informasi untuk meningkatkan daya saing bagi UMKM Kripik Salak Wono Mulyo dan Srikandi di Kabupaten Sleman adalah dengan memperkenalkan produk yang mereka buat secara lebih luas melalui penerapan e-commerce untuk pemasarannya. Electronic Commerce (e-commerce) merupakan konsep baru yang bisa digambarkan sebagai proses jual beli barang atau jasa pada world wide web internet (Suyanto, 2003; 11)

Pelaku usaha yang melakukan e-commerce harus memiliki situs usaha yang akan ditampilkan di internet. Tampilan tersebut berisi informasi mengenai produk yang ditawarkan di halaman paling utama dengan harapan produk tersebut mudah dikenali dan langsung bisa dilihat saat konsumen membuka situs tersebut. Setelah konsumen melihat, selanjutnya konsumen memutuskan untuk melakukan transaksi pembelian atau tidak. Kripik salak hasil produksi Gapoktan Wono Mulyo dan KWT Srikandi Kabupaten Sleman telah ditampilkan dalam website Gambar 1 dan Gambar 2. 


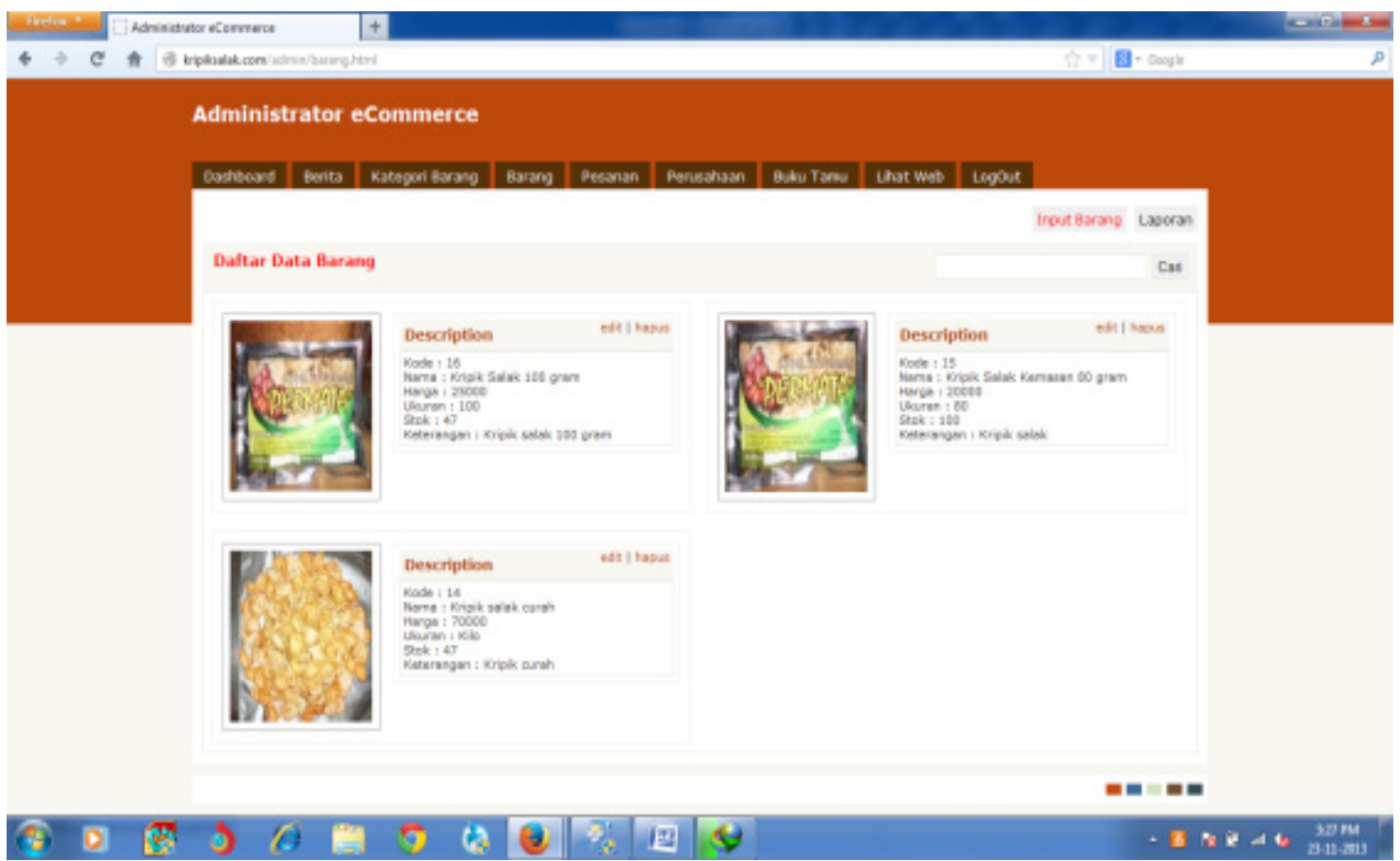

Gambar 1. Website Kripik Salak Gapoktan Wono Mulyo

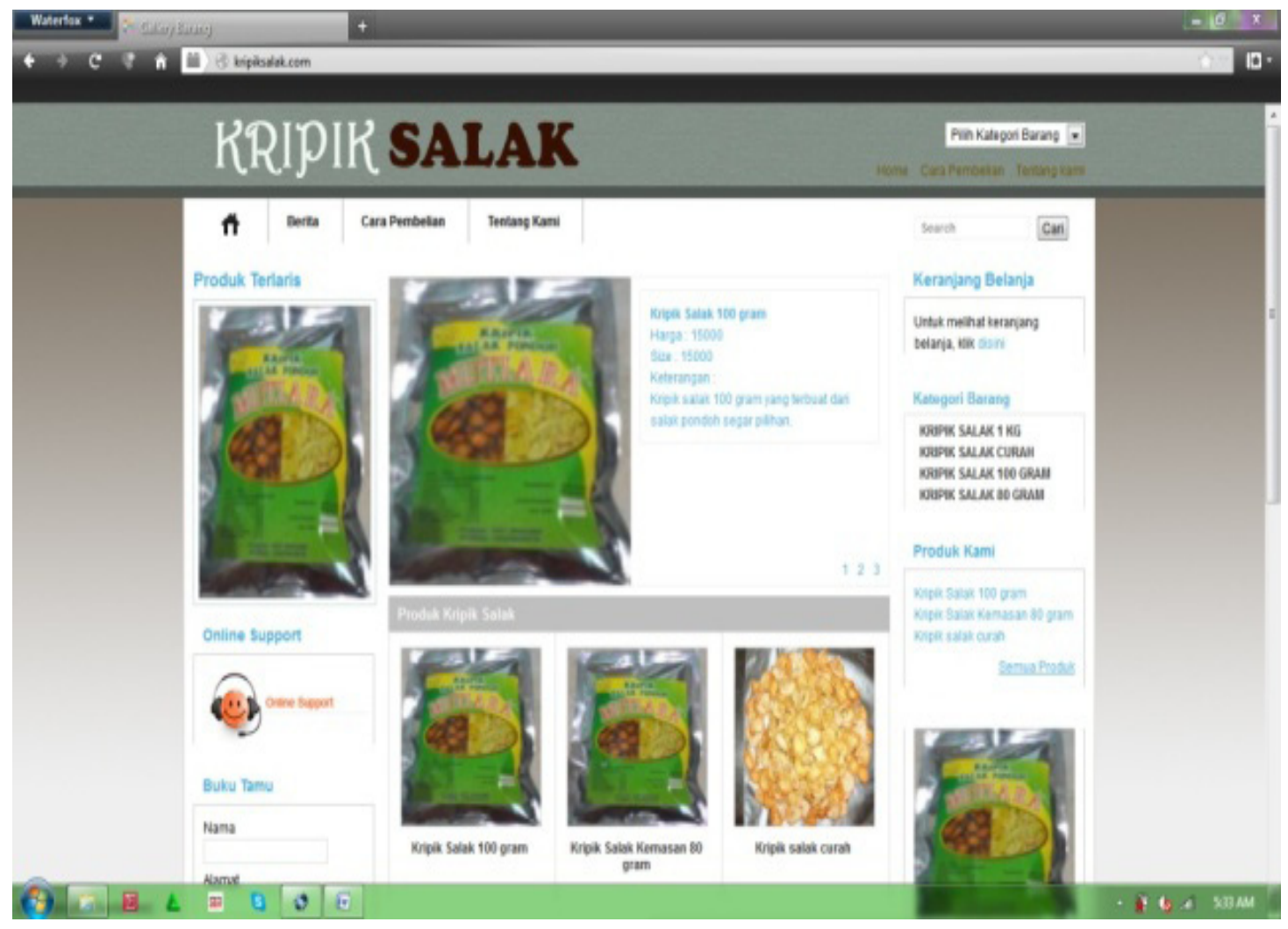

Gambar 2. Website Kripik Salak KWT Srikandi 


\section{KESIMPULAN}

Berdasarkan pembahasan tersebut disimpulkan bahwa peningkatan daya saing bagi UMKM kripik salak Gapoktan Wono Mulyo dan KWT Srikandi di Kabupaten Sleman adalah dengan melakukan serangkaian program sebagai berikut:

1. Pelatihan kewirausahaan mampu meningkatkan kualitas jiwa wirausaha yang dibuktikan dengan munculnya aspek kreatifitas, inovasi, dan keberanian dalam mengambil resiko.

2. Pelatihan pembukuan berjalan dengan baik, hal ini terbukti dengan adanya kemampuan operasional anggota UMKM dalam menentukan kos produksi, membuat catatan sediaan dengan menggunakan metoda FIFO serta penggunaan aplikasi MYOB dalam pembuatan laporan keuangan.

3. Penerapan teknologi dilakukan dengan pemanfaatan mesin teknologi yang tepat guna berupa continuous sealler dan genset, sedangkan di bidang teknologi informasi pembuatan desain web dilakukan untuk lebih meningkatkan pemasaran melalui e-commerce.

\section{REFERENSI}

Afiah, Nunuy Nur. 2009. Peran Kewirausahaaan dalam Memperkuat UMKM Indonesia menghadapi krisis finansial global. Working Paper in Accounting and Finance. FE Universitas Pajajaran. Bandung.

Baldwin, J R.1995. Innovation: The Key to Succes in Small Firms. Working Paper Series, Micro-Economic Studies and Analysis Division. Statistics Canada and Canadian Institute for Advanced Research Economic Project Growth. No 8.

Burgelman, R A., Maidique, Modesto A., and Wheelwright, Steven C. 2001. Strategic Management of Technology and Innovation, Third Edition, McGraw-Hill Irwin, New York USA.

Byrd et.al. 2002. Perspective on Innovation, McGraw-Hill Irwin, New York USA.

Chowdhury, A.H.M. 1990. Small and Medium Industries in Asian Developing Countries, Asian Development Review. Vol 1. pp29-45.

Jati, H.,Bala, Beatus dan Nisnoni. 2004. Menumbuhkan Kebiasaan Usaha Kecil Menyusun Laporan Keuangan, Jurnal Bisnis dan Usahawan, II no 8:210-218.

Kuncoro, Mudrajat. 2010. Masalah, Kebijakan dan Politik Ekonomika Pembangunan. Jakarta. Erlangga, p 196

Mahrinasari. 2003. Faktor-faktor yang Mempengaruhi Kualitas Jiwa Kewirausahaan Usaha kecil, Jurnal Entrepreneurship, Vol,1, No 2. Mei, 101-113.

Mukhyi, M A dan Mujiyana. 2008. Penerapan Teknologi Sistem Informasi dan Teknologi Tepat Guna pada Usaha Kecil Menengah. Proceeding, Seminar Ilmiah Nasional Komputer dan Sistem Intelejen, KOMMIT. 
Rahab dan Sudjono. 2012. Pengembangan Kapabilitas Keinovasian IKM berbasis pada orientasi kewirausahaan dan pembelajaran organisasional. Jurnal Inovasi dan Kewirausahaan. Volume 1. Januari 2012. Nomor 1. Halaman 29-37.

Situmorang, SH dan Syafri M. Urgensi Pengembangan Teknologi Tepat Guna untuk UMKM di Kota Medan. Jurnal Ekonom. Volume 14. Nomor 4. September 2012.

Sri Susilo. Y. 2005. Strategi Survival Usaha Mikro Kecil. (Studi Empiris Pedagang Warung Angkringan di Yogyakarta). Telaah Bisnis Vol. 6 No. 2 Desember 2005. Hal. 161-178.

Sri Susilo,Y. 2010. Strategi meningkatkan Daya Saing UMKM dalam Menghadapi Implementasi CAFTA dan MEA. Buletin Ekonomi vol 8. No. 2. Agustus. Hal 70-78.

Suliyanto dan Rahab. 2010. Peran orientasi pasar, kewirausahaan, pembelajaran organisasi pada kinerja UKM di Wilayah Kabupaten Banyumas (Laporan Penelitian), Purwokerto: Fakultas Ekonomi Universitas Jenderal Soedirman.

Suyanto M. 2003. Strategi Periklanan pada E-Commerce Perusahaan Top Dunia, Andi Yogyakarta.

Tidd, Joe., Bessant John., Pavitt, Keith. 1997. Managing Innovation: Integrating Technological, Market and Organizational Change, John Wiley and Sons, Inc. New York USA.

Wahdini dan Suhairi. 2006. Persepsi Akuntan terhadap Overload Standar Akuntansi Keuangan bagi Usaha Kecil dan Menengah. SNA IX Padang. 